\title{
Penyelenggaraan Pendidikan Inklusif Anak Berkebutuhan Khusus (Studi Multi Situs di SDN-4 Palangka dan SDN-3 Langkai Kota Palangka Raya)
}

\author{
Bedha Tamela ${ }^{1,2,}{ }^{*}$, Joni Bungai ${ }^{3}$, Wawan Kartiwa ${ }^{3}$ \\ 1 Alumni Program Studi Magister Pendidikan Dasar, Program Pascasarjana Universitas Palangka Raya, Kampus UPR Tunjung \\ Nyaho, Jl. Yos Sudarso Palangka Raya, Indonesia 73111 \\ 2 BTPN Syariah Kantor Cabang Palangka Raya \\ 3 Dosen Program Studi Pendidikan Dasar Program Pascasarjana Universitas Palangka Raya \\ * Korespondensi: Bedha Tamela (E-mail: bedha.tamela@yahoo.com)
}

\begin{abstract}
Every Indonesian citizen has the right to get education according to Article 31 paragraph (1) of the 1945 Constitution. To date, education for children with special needs (Anak Berkebutuhan Khusus/ABK) is held separately from the majority one. The separation, further, leads to the idea of inclusive education for all. This research aims to describe the implementation of inclusive education in SDN 4 Palangka and SDN-3 Langkai in Palangkaraya City. Besides, it looks for the supporting and inhibiting factors in its implementation. The data derived from observation, interviews and document analysis. The results confirm that the current implementation of inclusive education still needs substantial improvement and support, primarily in terms of qualified teaching staffs, facilities/infrastructure and funding. We found eleven supporting factors and four inhibiting factors influencing the implementation of inclusive education in SDN 4 Palangka and SDN-3 Langkai in Palangka Raya City.
\end{abstract}

Keywords

Inclusive education, children with special needs, basic education, Palangka Raya

\section{PENDAHULUAN}

Setiap anak memiliki fase perkembangan yang berbedabeda satu dengan yang lainnya. Setiap anak memiliki kekurangan dan kelebihannya masing-masing, demikian juga dengan anak yang memiliki berkebutuhan khusus. Keberadaan siswa yang berkebutuhan khusus di tengah masyarakat sering kali masih dinomor sekiankan dalam berbagai aspek kehidupan, salah satunya yang sering luput dari perhatian orang tua dan tenaga pendidik adalah mereka sebagai anak berkebutuhan khusus memerlukan pelayanan yang spesifik tidak sama dengan anak normal.

Kebijakan pemerintah tentang penuntasan wajib belajar pendidikan dasar sesuai dengan seruan Internasional Education For All (EFA) yang diungkapkan United Nations Educational, Scientific and Cultural Organization (UNESCO) pada tahun 2009. Hal ini juga sesuai dengan Pasal 31 UUD 1945 tentang hak setiap warga negara untuk memperoleh pendidikan dan Pasal
32 UU Nomor 20 tahun 2003 tentang Sistem Pendidikan Nasional yang mengatur mengenai pendidikan khusus dan pendidikan layanan khusus bagi siswa berkebutuhan khusus.

Selama ini dalam pendidikannya anak berkebutuhan khusus lebih banyak diselenggarakan secara segregasi (terpisah) di Sekolah untuk siswa yang berkebutuhan khusus SLB dan sekolah dasar untuk siswa yang khusus SDLB. Sementara itu lokasi SLB dan SDLB pada umumnya berada di ibukota kabupaten, siswa yang berkebutuhan khusus ada hampir di seluruh daerah di Kecamatan/Desa, akibatnya beberapa siswa tersebut tidak bersekolah karena lokasi sekolah untuk yang berkebutuhan kusus yang ada jauh dari tempat tinggalnya dan di sisi lain sekolah umum juga tidak memiliki kesiapan dalam menerima anak berkebutuhan kusus karena tidak bisa untuk memberikan layanan terbaik pada siswa berkebutuhan kusus di sekolahnya.

Keterpisahan anak yang berkebutuhan kusus (ABK) dengan kehidupan normal mereka hidup dalam 
lingkungan dan masyarakat yang dibangun dengan berbagai macam Indonesia menggunakan konsep yang di sebut dengan sekolah terpadu dengan anak-anak normal untuk ikut pendidikan di sekolah umum, konsep ini terus berkembang, hingga terbentuklah gagasan tentang pendidikan inklusif.

Ketika belajar anak yang berkebutuhan kusus sering melakukan kesalahan dalam penafsiran karen mereka mudah lupa, fakta yang tersimpan dapat tidak satu kerangka konteks yang terjadi. anak berkebutuhan kusus sebenarnya bisa memberi respon terhadap sesuatu pembelajaran, tetapi mereka akan sulit menghadapi situasi baru. Interaksi sosial anak berkebutuhan khusus kurang, represif,kurang kontak mata,sulit berinteraksi baik dengan teman ataupun tenaga pendidikan (guru), tidak bisa berempati,tidak memahami maksud orang lain,interaksi kesulitan menyampaikan keinginan, takut dan cenderung menghindari orang lain serta sulit memahami isyarat verbal-nonverbal. Anak berkebutuhan khusus sering kali kurang tangkas dalam gerak motorik kasar, sedangkan gerak motorik halus anak berkebutuhan kusus juga sering kali kurang terampil dan terkoodinir dalam melaksanakan salah satu tugas yang diberikan, ada beberapa macam penanganan anak yang berkebutuhan khusus yang dapat dipraktekan baik dari pihak orang tua maupun pihak lainnya, supaya anak berkebutuhan khusus ini bisa mengembangkan kemampuan dalam berinteraksi dan belajar dengan lingkungan sosial di sekitarnya.

Dalam hal ini diperlukan model pembelajaran yang kusus diberikan pada anak berkebutuhan khusus ini yaitu metode pembelajaran dengan berbagai aktivitas (untuk membantu mengoptimalkan kemampuan anak dan perilaku anak) dan membekali anak berkebutuhan khusus dengan keterampilan dan teknologi informasi supaya anak berkebutuhan khusus (ABK) dapat menerima pelajaran yang diberikan guru. Berdasarkan keterbatasan itu diperlukan layanan pendidikan khusus anak, anak berkebutuhan khusus dan pendidikan kusus lainnya dalam perkembangannya mengalami perkembangan yang pesat. Dalam pendidikan ABK kini telah mengalami banyak perubahan dan perkembangan, Dalam tahapnya pemerintah terus menambah jumlah sekolah inklusif dari tingkat Sekolah Dasar sampai Sekolah Menengah Atas.

Pemerintah daerah memberikan tugas kepada sekolah regular tertentu untuk melaksanakan pendidikan berkebutuhan khusus. Tantangan berat bagi pemerintah dan pendidikan luar biasa dalam pendidikan inklusif ini adalah ketersediaan guru-guru pembimbing anak berkebutuhan khusus. Dari sisi sumber daya manusia juga, karena guru-guru pada umumnya latar belakang pendidikannya, tidak memiliki pengetahuan dan kemampuan yang memadai untuk memberikan pendidikan dalam layanan untuk ABK. Idealnya di sekolah inklusif paling tidak ada satu guru dengan keahlian pendidikan luar biasa, guru pembimbing khusus (GBK) ini yang berberguna untuk membantu tenaga pendidikan yang ada di sekolah tersebut untuk memberi layanan pendidikan untuk ABK. Walaupun bergabung dengan siswa biasa, siswa bekebutuhan khusus ( $A B K$ ) mau tak mau tetap harus diawasi secara khusus, misalnya saja siswa yang berkebutuhan khusus harus diberi pendidikan yang kusus. Dengan ini waktu belajar dalam perlakuannya yang khusus akan lebih panjang dibanding dengan anak lain, inilah tantangan bagi guru-guru umum di sekolah inklusif.

Ada beberapa definisi tentang pendidikan inklusif. UNESCO (2009) menyebutkan bahwa pendidikan inklusif adalah proses penguatan sistem pendidikan agar dapat menjangkau seluruh siswa dengan demikian dapat dipahami sebagai strategi utama untuk mencapai pendidikan untuk semua. Peraturan Meteri Pendidikan Nasional No. 70 tahun 2012 menyebutkan bahwa pendidikan inklusif diberikan kepada semua anak terlepas dari kemampuan ataupun ketidak mampuan, status sosial dan ekonomi, suku bangsa, jenis kelamin dan latar belakang budaya bahasa dan agama menyatu dalam komunitas sekolah yang sama. Sedangkan, salah satu landasan filosofis dari penerapan pendidikan inklusif menjelaskan bahwa pendidikan inklusif merupakan pelaksanaan pendidikan multikultural sehingga membantu siswa untuk dapat mengerti, dan menerima, serta menghargai sesama yang berbeda suku, budaya, nilai, kepribadian, dan keberfungsian fisik atau psikologis.

Ahsan (2014) menyatakan pendidikan inklusif sebagai strategi yang layak untuk menciptakan pembelajaran lingkungan yang ramah untuk anak-anak/penyandang cacat, anak-anak dari etnis yang berbeda dan keragaman bahasa, anak-anak yang berasal dari latar belakang yang kurang beruntung secara sosial dan juga isu-isu gender. Dengan demikian, definisi ini memperkuat kedua definisi sebelumnya dimana pendidikan inklusif siswa dalam kasus atau hambatan yang bervariasi baik dari segi etnografi, cacat fisik, lingkungan dan sosial budaya, serta latar belakang, maupun gender.

Penerapan pendidikan inklusif memberikan dampak yang baik bagi semua pihak, terkhususnya untuk anak yang berkebutuhan khusus (ABK). Hasibuan dan Rahmawati (2019) menyatakan pendidikan inklusif sebagai praktek yang menjamin bahwa setiap anak dapat mencapai potensi terbaiknya secara penuh dengan tetap memperhatikan keunikan yang dimilikinya. Melalui pendidikan inklusif, dalam Deklarasi Bandung dalam DPPK dan PKLK Pendidikan Dasar (2012), anak berkebutuhan khusus memberi kesempatan akses untuk segala aspek kehidupan di masyarakat sehingga menjadi generasi penerus yang handal, memperoleh perlakuan manusiawi, mendapatkan pendidikan yang bermutu sesuai dengan potensi kebutuhan masyarakat serta mampu mengembangkan keunikan potensi secara optimal. Oleh karena itu, pendidikan inklusif dikatakan sebagai program pendidikan dalam rangka upaya mengembangkan kemampuan anak berkebutuhan khusus (ABK) dalam, psikomotorik, kognitif soft skills, dan karakter, dengan demikian anak berkebutuhan khusus 
akan hidup semakin bermakna setelah memperoleh pendidikan.

Kota Palangka Raya sebagai Kota Pendidikan Inklusif berlaku sejak tanggal pencanangannya yaitu 18 Oktober 2014 di kota Palangka Raya. kebijakan Disdikpora setempat yang diikuti dengan pembentukkan Kelompok Kerja (Pokja) Pendidikan Inklusif Kota Palangka Raya, pelaksanaan program Pendidikan Inklusif Dalam Peraturan Walikota Palangka Raya Nomor 26 Tahun 2014 tentang Penyelenggaraan Pendidikan Kusus, Pendidikan Inklusif dan Pusat Sumber di Kota Palangka Raya.

Dalam pendidikan anak yang berkebutuhan khusus di SDN 4 Palangka Kota Palangka Raya menerapkan pendidikan inklusif anak berkebutuhan khusus sekolah ini menerima anak-anak yang berkebutuhan khusus. SDN-4 Palangka Kota Palangka Raya ini sendiri berdiri pada tanggal 3 Agustus 2002 dengan status Negeri, SDN 4 Palangka Kota Palangka Raya berada di jalan Kini Balu, Palangka Raya, RT. 1 RW. 13, Kelurahan Palangka Kecamatan Jekan Raya, Kota Palangka Raya, Provinsi Kalimantan Tengah dan terdiri dari Kepala Sekolah 1 Orang, dengan jumlah Guru sebanyak 13 Orang, dan jumlah Karyawan Honorer sebanyak 4 orang, dan jumlah siswa sebanyak 203 orang dengan data ABK sebanyak 20 orang. SDN-3 Langkai berada di jalan Temanggung Tandang, Langkai, Kecamatan Pahandut, Kota Palangka Raya Provinsi Kalimantan Tengah berdiri pada tanggal 10 Januari 2001 dengan 1 kepala sekolah dan total tenaga pendidik 18 orang. Penelitian ini dilakukan di dua sekolah tersebut karena berdasarkan hasil observasi awal yaitu di SDN 4 Palangka Kota Palangka Raya yang merupakan satu-satunya sekolah pada jenjang Sekolah Dasar Negeri yang mempunyai salah satu tenaga pendidik yang berlatar belakang pendidikan inklusif dan menyelenggarakan pendidikan inklusif. Sedangkan di SDN-3 Langkai merupakan salah satu sekolah yang perduli dengan penyelenggarakan pendidikan inklusif di sekolahnya walaupun tenaga pendidiknya tidak berlatar belakang inklusif dan kedua sekolah ini sama-sama memiliki anak berkebutuhan khusus.

Penelitian ini bertujuan untuk mendeskripsikan penyelenggaraan pendidikan inklusif anak berkebutuhan khusus di SDN 4 Palangka dan SDN-3 Langkai Kota Palangka Raya. Selain itu juga untuk mengetahui faktor pendukung dan penghambat dari penyelenggaraan pendidikan inklusif anak berkebutuhan khusus di SDN 4 Palangka dan SDN-3 Langkai Kota Palangka Raya.

\section{METODOLOGI}

Penelitian adalah studi kasus dengan multi situs yang bertujuan untuk menggambarkan penyelenggaraan pendidikan inklusif pada anak berkebutuhan khusus pada SDN 4 Palangka dan SDN-3 Langkai di kota Palangka Raya. Informan pada penelitian ini yaitu Kepala Sekolah, Guru dan Siswa SDN 4 Palangka dan SDN 3 Langkai untuk memeperoleh informasi dalam Penyelenggaraan
Pendidikan Inklusif dan siswa berkebutuhan khusus. Pada pengambilan data sekunder informan yang dipilih yaitu Kepala sekolah SDN 4 Palangka dan SDN 3 Langkai di Kota Palangka Raya. Teknik pengambilan sampel pada proses ini, yaitu menggunakan teknik nonprobability sampling atau pengambilan sampel (informan penelitian) yang tidak memberikan peluang atau kesempatan yang sama untuk setiap unsur atau anggota populasi (orang/ masyarakat) untuk dapat dipilih atau diambil menjadi sampel (informan penelitian) Menurut Sugiyono (2013), jenis bentuk nonprobility sampling yang digunakan peneliti, yaitu purposive sampling atau pengambilan sampel (informan penelitian) dan/atau sumber data penelitian yang lain berdasar pertimbanganpertimbangan dan tujuan-tujuan yang selaras dan relevan dengan penelitian.

Data pada penelitian ini berupa data primer dan data sekunder. Data primer berupa jawaban, informasi dan tindakan dari informan yang dikumpulkan dari hasil wawancara. Sementara itu, data sekunder berasal dari arsip atau dokumen dari berbagai macam literatur dengan cara observasi dan dokumentasi. Teknik pengumpulan data yang digunakan, yaitu observasi, wawancara, dan dokumentasi.

Analisis data dilakukan dalam dua tahap, yaitu analisis data situs tunggal, dan analisis data lintas situs. Analisis situs tunggal dimulai dengan menelaah seluruh data yang telah terkumpul dari hasil wawancara, observasi catatan lapangan dan dokumentasi, guna meningkatkan pemahaman penelitian tentang persoalan yang sedang diteliti di masing-masing lapangan.

Data yang telah diperoleh dari situs tunggal pertama yaitu SDN 4 Palangka Kota Palangka Raya, dianalisa secara induktif konseptual sebagai langkah menemukan proposisi, selanjutnya menyusun teori substantif kemudian masuk pada proses analisis data pada situs kedua yaitu data yang diperoleh dari SDN-3 Langkai Kota Palangka Raya. Miles dan Huberman (1984) mengemukakan bahwa aktifitas analisis data pada penelitian kualitatif yang dilakukan secara interaktif berlangsung secara terus menerus sampai tuntas, sehingga datanya sudah jenuh. Aktifitas pada analisis data, yaitu data reduction, data display, dan data conclusion/drawing/verification. Langkah analisis data disajikan pada Gambar 1.

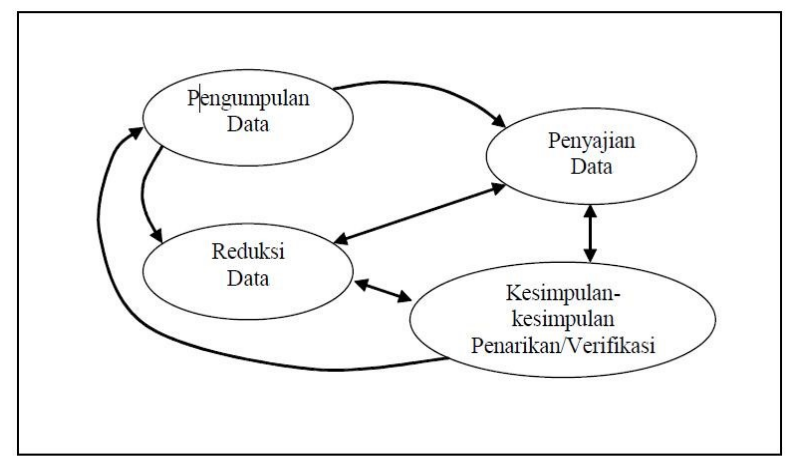

Gambar 1. Komponen analisis data 
Analisis data dilakukan dengan tiga tahapan, yaitu reduksi data, penyajian data, dan verifikasi/penarikan kesimpulan. Uji keabsahan data dilakukan dengan cara uji kredibilitas, transferabilitas, depandabilitas, dan konfirmabilitas. Menurut Moleong (2007), tahapan penelitian terdiri dari tahap pralapangan, tahap pekerjaan lapangan, tahap analisa data, dan tahap pelaporan hasil penelitian.

\section{HASIL}

\subsection{Deskripsi Lokasi Penelitian}

Penelitian ini di lakukan di dua sekolah yaitu di SDN 4 Palangka Kota Palangka Raya dan di SDN-3 Langkai Kota Palangka Raya yang merupakan salah satu sekolah penyelenggara pendirian inklusif sesuai dengan SK sekolah inklusif dari Keputusan Kepala Dinas Pendidikan Kota Palangka Raya 420/770.a/870.Um-Peg/VII/2019 tentang penunjukan Sekolah Penyelenggara Pendidikan Inklusif Kota Palangka Raya. Sekolah umum yang menyelenggarakan Pendidikan Inklusif ada 6 Sekolah jenjang Taman Kanak-kanak (TK), 11 Sekolah jenjang Sekolah Dasar (SD), dan 4 Sekolah Jenjang Sekolah Menengah Pertama (SMP)

SDN-4 Palangka Kota Palangka Raya ini berdiri pada tanggal 3 Agustus 2002 dengan No. SK Pendidrian sekolah 1501010341917. SDN 4 Palangka Kota Palangka Raya adalah salah satu sekolah jenjang Sekolah Dasar yang beralamat di Jalan Kini balu, Kelurahan Palangka Kota Palangka Raya. SDN 4 Palangka memiliki 205 siswa dan 21 diantaranya teridentifikasi adalah $A B K$ dengan hambatan Autism, HDHD, kesulitan belajar membaca, dan ketergantungan gadget. SDN 4 Palangka adalah salah satu Sekolah Dasar penyelenggara pendidikan inklusif di Kota Palangka Raya. SDN 4 palangka terdapat anak $A B K$ dengan jenis kelainan autis sebanyak 6 anak, dan 2 anak kesulitan belajar. Lokasi SDN 4 Palangka berada di Jalan Kini Balu, Palangka Raya, Kelurahan Palangka, Kecamatan Jekan Raya, Kota Palangka Raya, Provinsi Kalimantan Tengah 73112.

Visi SDN 4 Palangka Kota Palangka Raya adalah Menjadi Sekolah yang Inklusif, Berkarakter, Cerdas dan Asri. Misi SDN 4 Palangka Kota Palangka Raya adalah Sapta Karya Inovatif, yaitu: a) membangun kultur budaya sekolah berkarakter religius; b) menerapkan regulasi sesuai dengan asas hukum, politik dan sosial etik; c) mengembangkan kebutuhan sarana prasarana sekolah berstandar nasional; d) memfasilitasi integritas personal di dalam system sekolah yang informatif; e) meningkatkan kualitas personal yang religious, maju, mandiri dan sejahtera; f) meningkatkan proses operasional dan kurikulum sekolah secara efektif dan efisien; g) mensosialisasikan prestasi hasil pendidikan menjadi milik publik.

Sejarah berdirinya SDN-3 Langkai Kota Palangka Raya yaitu pada tanggal 26 September 1981. SDN 3 Langkai Kota Palangka Raya memiliki 9 orang anak berkebutuhan khusus yang terdiri dari 5 anak dengan gangguan kesulitan belajar, 2 anak tuna wicara, 1 anak tuna laras, dan 1 anak hiperaktif. SDN-3 Langkai beralamat di jalan Temanggung Tandang, Kelurahan Langkai, Kecamatan Pahandut, Kota Palangka Raya, Kalimantan Tengah.

Visi dari SDN-3 Langkai Kota Palangka Raya adalah Santun dalam budaya, berprestasi, dan menerapkan pola hidup ramah lingkungan. Misi SDN-3 Langkai Kota Palangka Raya diantaranya, yaitu: a) menanamkan rasa kebersamaan dan meningkatkan keimanan dan ketaqwaan melalui pengamalan ajaran agama; b) terwujudnya budaya tertib, disiplin, santun dalam ucapan, sopan terhadap prilaku terhadap sesame berlandaskan iman dan taqwa; c) menciptakan suasana kondusif dengan pendekatan pembelajaran aktif, Inovatif, Kreatif, Efektif dan Menyenangkan (PAIKEM); d) menumbuhkan semangat berprestasi kepada peserta didik; e) meningkatkan minat baca dengan memanfaatkan perpustakaan sebagai sumber ilmu; f) menjalin kerjasama yang harmonis antar warga sekolah dan lembaga lain yang terkait.

\subsection{Penyelenggaraan Pendidikan Inklusif}

Berdasarkan hasil wawancara, penulis menelaah bahwa dalam penyelenggaraan pendidikan inklusif memerlukan bantuan semua pihak baik sekolah, guru dan orang tua anak berkebutuhan khusus. Selain itu dari hasil wawancara peneliti menemukan hambatan yang dialami oleh pihak sekolah dalam penyelenggaraan pendidikan inklusif yaitu anggaran sekolah yang minim sehingga pihak sekolah dalam pengelolaan anggaran sekolah tersebut harus memperhatikan apa yang menjadi kebutuhan yang diprioritaskan oleh sekolah.

\section{- Penyediaan Tenaga Pendidik}

Berdasarkan hasil wawancara, penulis menelaah bahwa dalam penyediaan tenaga pendidik khusus itu perlu diperhatikan latar belakang pendidikannya dan keseriusannya dalam menghadapi anak berkebutuhan khusus dengan sabar.

\section{- Penjarinan dan Penyaringan ABK}

Dari hasil wawancara ditemukan bahwa dalam penjaringan dan penyaringan anak berkebutuhan khusus memerlukan bantuan semua pihak baik dari tenaga ahli, sekolah, guru dan orang tua anak berkebutuhan khusus, kemudian dari hasil wawancara di atas peneliti menemukan hambatan yang dialami oleh pihak sekolah dalam penyelenggaraan pendidikan inklusif yaitu dalam penjaringan menentukan jenis kelainan anak $A B K$ tersebut agar lebih mudah menentukan cara penangannya.

\section{- Kurikulum Sekolah}

Kurikulum yang digunakan dalam penyelenggaraan pendidikan inklusif di sekolah ini adalah kurikulum umum yaitu kurikulum 2013 dan menggunakan kurikulum 
modifikasi. Jadi sekolah menyesuaikan dengan kebutuhan anak berkebutuhan khusus. Berdasarkan hasil wawancara, penulis menelaah bahwa dalam menentukan kurikulum anak $A B K$ yaitu perlu memperhatikan apakah anak $A B K$ tersebut dapat mengikuti kurikulum yang ada atau tidak.

\section{- Proses Belajar Mengajar}

Dalam proses belajar mengajar yaitu anak-anak yang berkebutuhan khusus yang sudah mendapatkan guru pendamping itu didamping dalam proses belajar mengajarnya. Hasil wawancara menunjukkan bahwa dalam pnyelenggaraan pendidikan inklusif memerlukan bantuan semua pihak baik sekolah, guru dan orang tua anak berkebutuhan khusus, kemudian dari hasil wawancara di atas peneliti menemukan hambatan yang dialami oleh pihak sekolah dalam penyelenggaraan pendidikan inklusif yaitu anggaran sekolah yang minim sehingga pihak sekolah dalam pengelolaan anggaran sekolah tersebut harus memperhatikan apa yang menjadi kebutuhan yang diprioritaskan oleh sekolah.

\section{- Pelaksanaan Proses Belajar Mengajar}

Dalam pelaksanaan pendidikan inklusif, sekolah melakukan pembimbingan anak berkebutuhan khusus yang sudah ditentukan untuk ditangani oleh guru bimbingan khusus. Sehingga dalam pelaksanaan pembelajarannya bukan hanya di ruangan kelas tetapi juga bisa di luar kelas. Sebelum melaksanakan pembelajaran anak berkebutuhan khusus yang ADHD, guru kelas yang berada di kelas inklusif terlebih dahulu menyusun perencanaan pembelajaran. Perencanaan pembelajaran bertujuan untuk agar guru mengetahui apa yang akan dilakukan ketika melaksanakan pembelajaran. Rencana pelaksanaan pembelajaran anak berkebutuhan khusus yang digunakan guru adalah rencana pelaksanaan pembelajaran reguler.

Berdasarkan hasil wawancara dapat dijelaskan bahwa dalam pnyelenggaraan pendidikan inklusif memerlukan bantuan semua pihak baik sekolah, guru dan orang tua anak berkebutuhan khusus, kemudian dari hasil wawancara di atas peneliti menemukan hambatan yang dialami oleh pihak sekolah dalam penyelenggaraan pendidikan inklusif yaitu anggaran sekolah yang minim sehingga pihak sekolah dalam pengelolaan anggaran sekolah tersebut harus memperhatikan apa yang menjadi kebutuhan yang diprioritaskan oleh sekolah.

\section{- Alat dan Media Proses Belajar Mengajar}

Berdasarkan hasil pengamatan didapati bahwa guru menggunakan media sederhana dan mencoba memanfaatkan apa yang ada di sekitar lingkungan siswa. Guru dapat menggunakan potongan kertas ketika menyampaikan materi pelajaran tentang bangun datar. Media yang digunakan guru bermaksud menunjang penggunaan buku sebagai sumber belajar, sehingga siswa dengan mudah memahami materi yang diajarkan guru. Media yang digunakan untuk anak A dan anak $B$ berbeda. Salah satunya yaitu penggunaan teks untuk menunjang pembelajaran pada anak A dengan mata pelajaran Bahasa Indonesia, sedangakan anak B yaitu terdapat kartu kata, huruf tempel, alat tulis, kertas. Media tersebut digunakan oleh guru dalam membelajarkan mata pelajaran Bahasa Indonesia kepada anak B.

Penggunaan alat dan media pembelajaran untuk anak berkebutuhan khusus masih menggunakan media yang ada disekitar sekolah. Dalam hal ini untuk alat dan media pembelajaran untuk anak berkebutuhan khusus masih belum memadai guna menunjang penyelenggaraan pendidikan inklusif.

Dari hasil wawancara didapatkan bahwa dalam pnyelenggaraan pendidikan inklusif memerlukan bantuan semua pihak baik sekolah, guru dan orang tua anak berkebutuhan khusus, kemudian dari hasil wawancara di atas peneliti menemukan hambatan yang dialami oleh pihak sekolah dalam penyelenggaraan pendidikan inklusif yaitu anggaran sekolah yang minim sehingga pihak sekolah dalam pengelolaan anggaran sekolah tersebut harus memperhatikan apa yang menjadi kebutuhan yang diprioritaskan oleh sekolah.

\section{- Pendanaan}

Komponen keuangan sekolah merupakan komponen produksi yang menentukan terlaksananya kegiatan belajar mengajar dengan komponen lain. Dengan kata lain setiap kegiatan yang dilakukan memerlukan biaya.

Berdasarkan hasil wawancara ditemukan bahwa dalam pnyelenggaraan pendidikan inklusif memerlukan bantuan semua pihak baik sekolah, guru dan orang tua anak berkebutuhan khusus, kemudian dari hasil wawancara di atas peneliti menemukan hambatan yang dialami oleh pihak sekolah dalam penyelenggaraan pendidikan inklusif yaitu anggaran sekolah yang minim sehingga pihak sekolah dalam pengelolaan anggaran sekolah tersebut harus memperhatikan apa yang menjadi kebutuhan yang diprioritaskan oleh sekolah.

\subsection{Sistem Pembelajaran Pendidikan Inklusif}

Sistem pembelajaran pendidikan inklusif di SDN 4 Palangka Kota Palangka Raya yaitu menggunakan RRP umum. Rencana Pelaksanaan Pembelajaran (RPP) umum dibuat oleh guru kelas, jika anak berkebutuhan khusus tidak bisa mengikuti rencana pelaksanaan pembelajaran (RPP) umum maka guru pendamping membuat PPI berdasarkan hasil assesmen anak berkebutuhan khusus tersebut. Untuk anak yang berkebutuhan khusus tidak diharuskan berada di ruang kelas belajar tetapi juga bisa berada di luar kelas.

Sistem pembelajaran pendidikan inklusif di SDN 3 Langkai Kota Palangka Raya yaitu menggunakan RPP umum. Pelaksanaan pembelajaran di kelas ini dilakukan oleh guru kelas langsung dikarenakan SDN 3 Langkai ini tidak memiliki guru pendamping khusus jadi guru kelas yang merangkap jadi guru pendamping khusus bagi anak berkebutuhan khusus. 


\subsection{Faktor-faktor Pendukung Penyelenggaraan Pendidikan Inklusif}

Adapun faktor-faktor pendukung penyelenggaraan pendidikan inklusif di SDN 4 Palangka dan SDN 3 Langkai Kota Palangka Raya diantaranya sebagai berikut:

1. Adanya komitmen yang sungguh-sungguh dari kepemimpinan, manajemen, dan seluruh pendidik (kepala sekolah, guru, dan staf)

2. Adanya kesatuan cara pandang dan sikap positif dari seluruh penyelenggara sekolah dalam menerapkan budaya inklusif

3. Kebijakan sekolah yang mendukung

4. Guru-guru dapat bekerja sama dalam tim dan mampu bekerja secara koperatif

5. Adanya koordinasi yang baik antara guru kelas dan guru pedamping khusus

6. Kemampuan guru dalam mengajar dan strategi menerapkan kurikulum yang tepat di kelas.

7. Adanya tenaga pendukung yang memadai (guru pendamping khusus)

8. Terbukanya akses siswa mendapatkan layanan khusus di luar sekolah (terapi)

9. Keterlibatan dan dukungan orang tua dan keluarga

10. Ada rencana pembelajaran individu untuk anak-anak yang memiliki masalah belajar dan perilaku yang signifikan

11. Siswa memiliki perasaan diterima dan dihargai di lingkungan sekolah.

\subsection{Faktor Penghambat Penyelenggaraan Pendidikan Inklusif}

Faktor- faktor yang menghambat proses manajemen layanan peserta didik inklusif di SDN 4 Palangka Kota Palangka Raya dan SDN 3 Langkai Palangka Raya meliputi faktor internal dan faktor eksternal, faktor internal yaitu Guru-guru di SDN 4 Palangka Kota Palangka Raya dan SDN 3 Langkai belum semuanya mengukuti penataran atau workshop tentang prosedur mengajar atau memberikan pelayanan kepada peserta didik inklusif, dan belum adanya guru pembimbing khusus untuk peserta didik inklusif, faktor eksternal, orang tua menyerahkan anak sepenuhnya kepada sekolah dan tidak bertanggung jawab lagi terhadap perkembangan pendidikannya.

Pada dasarnya anak seusia siswa Sekolah Dasar masih memiliki karakteristik yang suka bermain yaitu siswa yang masih banyak bermain dibandingkan dengan belajar. Jadi, harus sering diingatkan dalam aturan dan pelaksanaan proses pembelajaran. Keadaan yang seperti itulah yang kadang menghambat kegiatan belajar mengajar antara guru dengan siswanya. Faktor penghambatnya yaitu dari sisi siswa, kalau dia memang belum mampu mengikuti pembelajaran ya harus didampingi karena pada dasarnya anak lebih banyak cenderung bermain dari pada belajar. Faktor penghambat yang sering ditemui guru yaitu pada siswa yang cenderung tidak bisa terus-menerus mengikuti tahap-tahapan proses pembelajaran yang disampaikan guru. Solusinya dengan guru pendamping selalu siaga mendampingi anak berkebutuhan khusus yang terkadamg tidak bisa mengikuti mata pelajaran tertentu. Sehingga, guru kelas maupun guru pendamping harus berkreatif secara maksimal untuk membantu anak berkebutuhan khusus yang belum bisa atau terlambat dalam menerima pelajaran.

Faktor penghambat penyelenggaraan pendidikan inklusif di SDN 4 Palangka Kota palangka Raya dan SDN 3 Langkai, yaitu: a) trbatasnya dana untuk penyediaan media pendidikan yang dibutuhkan; b) minimnya kreatifitas dikalangan masyarakat dikalangan masyarakat dalam menyediakan media pendidikan; c) terbatasnya sumber daya manusia (SDM) yang memiliki kemampuan dalam penyampaian pesan-pesan pembelajaran kepada anak berkebutuhan khusus; d) Kurangnya sosialisasi tentang penyelenggaraan pendidikan inklusif.

\section{PEMBAHASAN}

Kebijakan pemerintah sebagai komitmen untuk mewujudkan penyelenggaraan pendidikan inklusif di Indonesia dapat ditandai dengan lahirnya Undangundang berikut, diantaranya adalah Undang-Undang nomor 4 tahun 1997 pasal 5 tentang pernyandang anak cacat; Undang-Undang nomor 23 tahun 2002 pasal 48 dan 49 tentang perlindungan anak; Undang-Undang nomor 20 tahun 2003 pasal 5, ayat 1 sampai dengan 4 tentang sistem pendidikan Nasional; Surat Edaran Dirjen Manajemen Pendidikan Dasar dan Menengah, Kemendiknas nomor. 380/C.C6/MN/2003, tanggal 20 Januari 2003; Permendiknas nomor 70 tahun 2009 tentang Pendidikan Inklusif; PP nomor 17 tahun 2010 pasal 127 sampai dengan 142, tentang Pengelolaan dan Penyelenggaraan Pendidikan.

Hal ini berarti pemerintah telah berupaya untuk mengimplementasikan kebijakan yang telah dibuat. Dari data yang diperoleh, tampaknya implementasi yang telah dilakukan menunjukan kuantitas yang progresif, namun pertanyaannya, apakah benar implementasi penyelenggaraan tersebut telah berhasil. Seperti dikatakan Pressman dan Wildavsky dalam Wahab (2015) menyataka bahwa proses untuk melaksanakan kebijakan perlu mendapatkan perhatian yang seksama. Oleh sebab itu, keliru jika kita menganggap bahwa proses tersebut dengan sendirinya akan berlangsung mulus. Sedangkan Hogwood \& Gunn dalam Wahab (2015) menyatakan bahwa kebijakan publik itu sebenarnya mengandung resiko untuk gagal. Kegagalan dalam implementasi kebijakan bisa dilihat dari dua kategori besar, yaitu nonimplemetation dan unsuccessfull implementation. Apa yang telah dilakukan pemerintah untuk mengimplementasikan kebijakannya tidak termasuk dalam dua kategori ini, namun juga tidak serta merta dianggap sebagai keberhasilan yang mutlak. 
Untuk mengevaluasi apakah implementasi kebijakan tersebut sudah berhasil atau belum, maka harus pula ditinjau dari sisi makna pendidikan inklusif dan konten kebijakan yang meladasi implementasi kebijakannya. Misalnya dalam makna pendidikan inklusif disebutkan dalam pasal 1 Peraturan Menteri Pendidikan Nasional RI nomor 70 tahun 2009 menyebutkan, bahwa pendidikan inklusif adalah sistem penyelenggaraan pendidikan yang memberikan kesempatan kepada semua peserta didik yang memiliki kelainan dan memiliki potensi kecerdasan dan/atau bakat istimewa untuk mengikuti pendidikan atau pembelajaran dalam satu lingkung pendidikan secara bersama-sama dengan peserta didik pada umumnya; Kemudian dilanjutkan dalam pasal 2, bahwa pendidikan inklusif bertujuan: (a) Memberikan kesempatan yang seluas-luasnya kepada semua peserta didik yang memiliki kelainan fisik, emosi, mental, dan sossial atau memiliki potensi kecerdasan dan/atau bakat istimewa untuk memperoleh pendidikan. (b) Mewujudkan penyelenggaraan pendidikan yang menghargai keanekaragaman, dan tidak diskriminatif bagi semua peserta didik, pertanyaannya makna ini telah terwujud menjadi sebuah kenyataan dalam implementasi kebijakan, tentunya hal ini masih dapat disanggah dengan perkataan mana mungkin kebijakan itu mampu mengasilkan perubahan seketika. Apapun sanggahannya evaluasi tetap harus diarahkan pada pemahaman makna dari pendidikan inklusif itu sendiri.

Berikutnya, Menurut UU No. 20 tahun 2003 pasal 3, tujuan pendidikan nasional adalah berkembangnya potensi peserta didik agar menjadi manusia yang beriman dan bertaqwa kepada Tuhan Yang Maha Esa, berakhlak mulia, sehat, berilmu, cakap, kreatif, mandiri, dan menjadi warga Negara yang demokratis dan bertanggungjawab. Melalui pendidikan peserta didik berkelainan dibentuk menjadi warga Negara yang demokratis dan bertanggungjawab, yakni individu yang mampu menghargai perbedaan, berpartisipasi dalam masyarakat. Tentunya ini masih menjadi pekerjaan besar untuk mengiplementasikan kebijakan tersebut.

Meski sudah diterbitkan kebijakan yang secara yuridis mempunyai kekuatan hukum, namun dalam penyelenggaraannya masih banyak persoalan yang terjadi pada SDN 4 Palangka Kota Palangka Raya (situs 1) dan SDN 3 Langkai Kota Palangka Raya (situs 2), yaitu:

1. Kurangnya pemahaman tentang pendidikan inklusif

2. Kebijakan sekolah

3. Proses pembelajaran, misalnya guru masih belum bisa menerjemahkan kurikulum yang fleksibel, menetukan tujuan sampai pada evaluasi

4. Kondisi guru, belum adanya guru yang memiliki kualitas memadai sebagai guru pendidikan inklusif

5. Media pembelajaran yang masih minim

6. Pendanaan dalam penyelenggaraan pendidikan inklusif yang masih kurang

7. Lingkungan yang kurang mendukung penyelenggaraan pendidikan inklusif.
Dari berbagai dilema yang terjadi pada pendidikan inklusif di sekolah, setidaknya harus segera diantisipasi dengan kebijakan-kebijakan khusus agar tidak menghalangi pelaksanaan implementasi kebijakan tentang pendidikan inklusif. Menurut Sunardi (2009) ada beberapa dilema yang perlu ditangani dengan kebijakan khusus, yakni:

1. Sistem penerimaan siswa baru, khususnya di tingkat pendidikan menengah dan atas yang menggunakan nilai ujian nasional sebagai kreteria penerimaan. Siswa hanya dapat diterima kalau hassil ujian nasionalnya memenuhi standar minimal yang telah ditetapkan oleh masing-masing sekolah

2. Dijadikannya pencapaian hasil ujian nasional sebagai kriteria sekolah bermutu, bukan diukur dari kemampuannya dalam mengoptimalkan kemampuan siswa secara komperhensip sesuai dengan keragaman

3. Penggunaan label sekolah inklusif dan adanya PP nomor 19 tahun 2005 tentang standar Nasional Pendidikan, pasal 41 ayat 1 tentang keharusan untuk memiliki tenaga kependidikan khusus bagi sekolah inklusif sebagai alasan melakukan penolakan masuknya anak berkelainan ke sekolah yang bersangkutan, yang ditandai dengan munculnya gejala 'esklusivisme baru', yaitu menolak anak berkebutuhan khusus dengan alasan belum memiliki tenaga khusus atau sekolahnya bukan sekolah inklusif.

4. Kurikulum pendidikan umum yang ada sekarang ini belum mengakomodasi keberadaan anak-anak yang memiliki perbedaan kemampuan (difabel)

5. Masih dipahaminya pendidikan inklusif secara dangkal, yaitu semata-mata memasukkan anak disabled children ke sekolah regular, tanpa upaya untuk mengakomodasi kebutuhan khhususnya. Kondisi ini dapat menjadikan anak tetap tereklusi dari lingkungan karena anak merasa tersisih, terisolasi, ditolak, tidak nyaman, sedih, marah, dan sebagainya. Pada hal makna inklusif adalah ketika lingkungan kelas atau sekolah mampu memberikan rasa senang, menerima, ramah, bersahabat, peduli, mencintai, menghargai, serta hidup dan belajar dalam kebersamaan

6. Munculnya lebel khusus yang sengaja diciptakan oleh pemerintah maupun masyarakat yang cenderung membentuk sikap eklusivisme, seperti sekolah unggulan, sekolah berstandar internasional (SBI), Sekolah Rintisan Berstandar Internasional (RSBI), Sekolah favorit, sekolah percontohan, kelas akselerasi, serta sekolah-sekolah yang berbasis agama. Kondisi ini tentu dapat berdampak kepada sekolah inklusif sebagai sekolah kelas dua (second class), karena menerima $A B K$ sama dengan special school menurut Imam Subakhan (2009)

7. Masih terbatasnya perhatian dan keseriusan pemerintah dalam mempersiapkan pendidikan 
inklusif secara matang dan komperhensif, baik dari aspek sosialisasi, penyiapan sumberdaya, maupun uji coba metode pembelajaran, sehingga hanya terkesan program eksperimental.

Penelitian ini telah menyajikan data dan temuan penelitian di SDN 4 Palangka dan SDN 3 Langkai Kota Palangka Raya. Oleh karena itu selanjutnya akan di lanjutkan dengan menganalisis yang berdasarkan pada temuan penelitian dengan menyajikan persamaan dan perbedaan kedua sekolah tersebut, meskipun dari hasil temuan penelitian menyimpulkan lebih banyak persamaannya akan tetapi dalam persamaan tersebut masih ada sedikit perbedaan di dalam komponennya. Berikut akan di jelaskan analisis tersebut yang berdasarkan dari hasil temuan penelitian.

\section{- Persamaan}

Persamaan antara SDN-4 Palangka Kota Palangka Raya dan SDN 3 Langkai Kota Palangka Raya yaitu samasama sekolah umum yang menyelenggarakan pendidikan inklusif di Kota Palangka Raya sesuai dengan SK Kepala Dinas Nomor 420/770.a/870.Um-Peg/VII/2019. Untuk sarana dan prasarana masih belom memadai untuk penyelengaraan pendidikan inklusif khususnya anak berkebutuhan khusus, dan dalam pendanaan juga samasama mengharapkan bantuan dari orang tua siswa sedangkan bantuan dari pemerintah masih tidak tersampaikan.

\section{- Perbedaan}

Perbedaan SDN 4 Palangka Kota Palangka Raya dan SDN 3 Langkai Kota Palangka Raya yaitu dalam perlakuan terhadap anak berkebutuhan khusus yaitu di SDN 4 Palangka Kota Palangka Raya adanya guru bimbingan khusus untuk anak berkebutuhan khusus dan ada rencana pembelajaran individu untuk anak-anak yang memiliki masalah belajar dan perilaku yang signifikan sedangkan untuk sekolah SDN-3 Langkai tidak ada guru bimbangan khusus serta tidak ada rencana pembelajaran individu untuk anak-anak yang memiliki masalah belajar dan perilaku yang signifikan.

\section{KESIMPULAN}

Berdasarkan hasil penelitian yang telah dilakukan diperoleh beberapa kesimpulan diantaranya yang pertama adalah gambaran penyelenggaraan pendidikan inklusif di SDN 4 Palangka dan SDN 3 Langkai. Secara keseluruhan terkait gambaran ini penulis menyimpulkan sebagai berikut: a) mempunyai dasar penyelenggaraan pendidikan inklusif dengan adanya SK dari Kepala Dinas no 420/770.a/870.Um-Peg/VII/2019; b) sekolah menerima semua anak berkebutuhan khusus; c) dari aspek manajemen kepegawaian atau pendidik, tidak semua sekolah inklusif memiliki GPK bahkan sekolahsekolah di Indonesia belum mampu menyediakan guru yang berkualifikasi sesuai bidangnya; d) dari aspek manajemen sarana prasarana, tidak semua sekolah mampu memenuhi kebutuhan sarpras yang dibutuhkan peserta didik. Sejauh ini masih menggunakan apa yang ada di sekolah; e) dari aspek manajemen keuangan sekolah-sekolah merasa memiliki keterbatasan dana untuk memenuhi kebutuhan sekolah; f) dari aspek pelaksanaan pembelajaran belum sesuai dengan semestinya yakni pembelajaran masih dilakukan secara umum, jadi ABK menyesuaikan keadaan kelas bukan kelas yang mengikui keadaan $A B K$; g) dari aspek evaluasi pembelajaran dianggap rendah, hal ini di karnakan peserta didik $A B K$ menggunakan standar kelulusan yang sama dengan siswa normal; h) dari sisi perencanaan pembelajaran khususnya dalam menyusun RPP, guru merasa kesulitan dalam menuangkan indikator dalam materi yang harus disesuaikan dengan kemampuan dan karakteristik ABK. Demikian juga dalam menyiapkan bahan/materi dan sumber belajar; i) dalam kegiatan evaluasi pembelajaran, guru merasa kesulitan dalam memberikan penilaian kepada ABK dikarenakan tidak adanya petunjuk dan panduan yang baku sehingga penilaian yang diberikan guru kepada ABK lebih bersifat subyektif; j) dari aspek manajemen lingkungan, sekolah selalu melibatkan orang tua. Artinya guru-guru selalu aktif berkomunikasi dengan orangtua $A B K$, dengan harapan bahwa terjalin kerjasama antar sekolah dengan orang tua siswa maka proses pembelajaran di sekolah maupun di rumah akan tercipta dengan baik.

Keadaan Guru Pendamping Khusus pada Sekolah Dasar inklusif di Indonesia, dalam implementasinya masih terdapat kekurangan guru, terutama GPK. Hal ini dikarenankan adanya kendala kurangnya sumber daya guru, khususnya GPK di daerah. Keberadaan mereka masih dirasakan menjadi masalah utama, khususnya bagi sekolah yang lokasinya jauh dari SLB, karena seringkali GPK merupakan guru SLB yang mendapat tugas khusus. Penugasan khusus guru SLB seringkali menjadi masalah karena kebijakan tentang hal ini belum berjalan semestinya. Adanya kewajiban berupa tugas, tentunya juga harus dibarengi adanya hak yang harus diperoleh oleh Guru Pembimbing Khusus (GPK) menyangkut pelaksanaan tugas-tugasnya. GPK perlu pengakuan atas tugas yang dilaksanakan, baik berupa SK sebagai GPK dari dinas terkait dalam hal ini Dinas Pendidikan setempat.

Selanjutnya juga pengakuan atas jam mengajar di sekolah inklusif yang berhubungan langsung dengan angka kredit sebagai bahan untuk kenaikan pangkat. Disisi lain, GPK disamping bertugas di Sekolah Luar Biasa (SLB) sebagai sekolah induknya, mereka juga harus datang ke sekolah inklusif yang menjadi tanggungjawabnya. Adapun jenis siswa berkebutuhan khusus yang menjadi siswa inklusif yaitu tunanetra, 
tunarungu, tunagrahita ringan, tunagrahita sedang, tunadaksa ringan, tunadaksa sedang, tunalaras, tunawicara, hiperaktif, cerdas istimewa, bakat istimewa, kesulitan belajar, korban narkoba, indigo, down sindrome, autis, dan tunaganda.

Faktor Pendukung dalam penyelenggaraan pendidikan inklusif pada penelitian ini diantaranya, yaitu: 1) adanya komitmen yang sungguh-sungguh dari kepemimpinan, manajemen, dan seluruh pendidik (kepala sekolah, guru, dan staf); 2) adanya kesatuan cara pandang dan sikap positif dari seluruh penyelenggara sekolah dalam menerapkan budaya inklusif; 3) kebijakan sekolah yang mendukung; 4) guru-guru dapat bekerja sama dalam tim dan mampu bekerja secara koperatif; 5) adanya koordinasi yang baik antara guru kelas dan guru pedamping khusus; 6) kemampuan guru dalam mengajar dan strategi menerapkan kurikulum yang tepat di kelas; 7) adanya tenaga pendukung yang memadai (guru pendamping khusus); 8) terbukanya akses siswa mendapatkan layanan khusus di luar sekolah (terapi); 9) keterlibatan dan dukungan orang tua dan keluarga; 10) ada rencana pembelajaran individu untuk anak-anak yang memiliki masalah belajar dan perilaku yang signifikan; 11) siswa memiliki perasaan diterima dan dihargai di lingkungan sekolah.

Faktor penghambat penyelenggaraan pendidikan inklusif ini dapat menjadi perhatikan pemerintah, masyarakat, orang tua, dan sekolah agar dapat bekerjasama dalam mencapai tujuan penyelenggaraan pendidikan inklusif. Faktor penghambat tersebut diantaranya adalah: 1) terbatasnya dana untuk penyediaan media pendidikan yang dibutuhkan; 2) minimnya kreatifitas dikalangan masyarakat dalam menyediakan media pendidikan; 3) terbatasnya sumber daya manusia yang memiliki kemampuan dalam penyampaian pesan-pesan pembelajaran anak berkebutuhan khusus; 4) kurangnya sosialisasi tentang penyelenggaraan pendidikan inklusif.

\section{DAFTAR PUSTAKA}

Ahsan, M. T., 2014. Inclusive Education: A Strategy to Address Diversity to Ensure Equal Right to Education. Editorial. Asian Journal of Inclusive Education (AJIE), 2 (1), 1-3.

Deklarasi Bukittinggi. 2012. Direktorat Pendidikan Khusus dan Layanan Khusus (PKLK) Pendidikan Dasar

Hasibuan, A.T. and Rahmawati, R., 2019. Sekolah Ramah Anak Era Revolusi Industri 4.0 di SD Muhammadiyah Pajangan 2 Berbah Yogyakarta. Al-Bidayah: Jurnal Pendidikan Dasar Islam, 11(1), 49-76.

Miles, M. B., and Huberman, A. M., 1984. Drawing valid meaning from qualitative data: Toward a shared craft. Educational researcher, Sage Journal Publication, 13(5), 20-30.

Moleong, L. J., 2007. Metode penelitian kualitatif. Bandung: PT. Remaja Rosdakarya.

Peraturan Walikota Palangka Raya Nomor 26 tahun 2014 tentang Penyelenggaraan Pendidikan Khusus, Pendidikan Inklusif dan Pusat Sumber di Kota Palangka Raya.

Permendiknas Nomor 70 Tahun 2009 tentang Pendidikan Inklusif Bagi Peserta Didik Yang Memiliki Kelainan dan Memiliki Potensi Kecerdasan dan/atau Bakat Istimewa.

Sugiyono, 2013. Penelitian Kualitatif. CV Alvabeta, Bandung.

Sunardi, 2009. Issues and Problems on Implementation of Inclusive Education for Disable Children In Indonesia. Tsukuba: CRICED-University of Tsukuba.

Undang-Undang Nomor 32 tahun 2004 tentang Pemerintah Daerah.

Undang-Undang Dasar 1945 (Amandemen) Hak Setiap Warga Negara Memperoleh Pendidikan.

Undang-Undang Nomor 20 tahun 2003, Tentang Sistem Pendidikan Nasional.

UNESCO, 2009. Overcoming Exclusion Through Inclusive Approaches in Education, a Challenge and Vision, Concotual Paper.

Wahab, S. A., 2015. Analisis Kebijakan: Dari Formulasi ke Penyusunan Model Implementasi Kebijakan Publik. Jakarta: Bumi Aksara. 